\title{
Houttuynia cordata Thunb inhibits the production of pro-inflammatory cytokines through inhibition of the NFkB signaling pathway in HMC-1 human mast cells
}

\author{
HEE JOE LEE ${ }^{1 *}$, HYE-SOOK SEO ${ }^{2 *}$, GYUNG-JUN KIM ${ }^{1}$, CHAN YONG JEON ${ }^{1}$, \\ JONG HYEONG PARK ${ }^{1}$, BO-HYOUNG JANG ${ }^{2}$, SUN-JU PARK ${ }^{2}$, YONG-CHEOL SHIN ${ }^{2}$ and SEONG-GYU KO ${ }^{2}$ \\ ${ }^{1}$ Department of Oriental Medicine, Kyongwon University, Seongnam, Gyeonggi-Do 461-701; \\ ${ }^{2}$ Laboratory of Clinical Biology and Pharmacogenomics and Center for Clinical Research and Genomics, \\ Institute of Oriental Medicine, Kyung Hee University, Seoul 130-701, Republic of Korea
}

Received March 7, 2013; Accepted June 17, 2013

DOI: $10.3892 / \mathrm{mmr} .2013 .1585$

\begin{abstract}
Houttuynia cordata Thunb (HCT) is widely used in oriental medicine as a remedy for inflammation. However, at present there is no explanation for the mechanism by which HCT affects the production of inflammatory cytokines. The current study aimed to determine the effect of an essence extracted from HCT on mast cell-mediated inflammatory responses. Inflammatory cytokine production induced by phorbol myristate acetate (PMA) plus a calcium ionophore, A23187, was measured in the human mast cell line, HMC-1, incubated with various concentrations of HCT. TNF- $\alpha$, IL- 6 and IL- 8 secreted protein levels were measured using an ELISA assay. TNF- $\alpha$, IL- 6 and IL- 8 mRNA levels were measured using RT-PCR analysis. Nuclear and cytoplasmic proteins were examined by western blot analysis. The NF- $\mathrm{KB}$ promoter activity was examined by luciferase assay. It was observed that HCT inhibited PMA plus A23187-induced TNF- $\alpha$ and IL- 6 secretion and reduced the mRNA levels of TNF- $\alpha$, IL- 6 and IL-8. It was also noted that HCT suppressed the induction of NF- $\mathrm{kB}$ activity, inhibited nuclear translocation of NF- $\kappa \mathrm{B}$ and blocked the phosphorylation of IкB $\alpha$ in stimulated HMC-1 cells. It was concluded that HCT is an inhibitor of NF- $\mathrm{KB}$ and cytokines blocking mast cell-mediated inflammatory responses. These results indicate that HCT may be used for the treatment of mast cell-derived allergic inflammatory diseases.
\end{abstract}

Correspondence to: Dr Seong-Gyu Ko, Laboratory of Clinical Biology and Pharmacogenomics and Center for Clinical Research and Genomics, Institute of Oriental Medicine, Kyung Hee University, 26 Kyungheedae-ro, Seoul 130-701, Republic of Korea E-mail: epiko@khu.ac.kr

${ }^{*}$ Contributed equally

Key words: Houttuynia cordata Thunb, allergic inflammation, human mast cells, NF- $\kappa \mathrm{B}$, pro-inflammatory cytokine

\section{Introduction}

Inflammation is part of the complex biological response of vascular tissue to harmful stimuli, including pathogens, damaged cells or irritants (1). This inflammation is associated with cytokines and pro-inflammatory mediators secreted from macrophages. An allergic reaction is the result of an inappropriate immune response triggering inflammation (2). A common example is hay fever, which is caused by a hypersensitive response by skin mast cells to allergens (3). During allergic inflammation, immunoglobulin E ( $\operatorname{IgE})$ is produced against allergen infiltration resulting in activation of mast cells, which releases histamine, TNF- $\alpha$, IL-6, IL-8 and NF- $\mathrm{KB}$ (4). Histamine is produced by basophils and by mast cells located in nearby connective tissues (5). Histamine binds to the $\mathrm{H} 1$ receptor in target cells to contract gut and bronchus smooth muscle and to increase venular permeability and rheum (6). Histamine increases the permeability of capillaries to white blood cells and various proteins to allow them to engage pathogens in the infected tissue (6). TNF- $\alpha$ is secreted during the allergic mechanism by mast cells, macrophages and T cells. TNF- $\alpha$ causes the expression of adhesion factors to vascular endothelial cells and accumulates white blood cells resulting in an inflammatory response $(7,8)$. IL-6 causes a chronic inflammatory response, activating $\mathrm{T}$ cells and producing IgE (9). IL-8 functions as a chemotactic factor for neutrophils, eosinophils and $\mathrm{T}$ lymphocytes activating an inflammatory response (10). NF- $\mathrm{KB}$ acts as a transcription factor binding to an NF- $\mathrm{KB}$ response element located at the promoter of target genes, regulating TNF- $\alpha$, IL- 6 and IL-8 $(11,12)$. The secretion of histamine, TNF- $\alpha$, IL- 6 , IL-8 and NF- $\kappa \mathrm{B}$ is important in the inflammatory response and appropriate regulation of these molecules may be useful for the treatment of inflammatory disease.

Houttuynia cordata Thunb (HCT), a perennial herb, known as 'E-Sung-Cho' in Korea, is widely distributed throughout Southeast Asia. Antiviral, anticancer, antileukemic, antioxidant and antiallergic activities of HCT have previously been reported (13-17). HCT may be beneficial for the treatment of mast cell-mediated inflammation $(18,19)$. In addition, HCT 
extract induces apoptosis via the mitochondrial-dependent pathway in HT-29 human colon adenocarcinoma cells (20).

In the present study, the therapeutic effect of HCT on allergic inflammatory disease was investigated. The levels of TNF- $\alpha$, IL-6 and IL-8 in HMC-1 human mast cells activated by PMA and A23187 under treatment with HCT were measured. HCT inhibited PMA plus A23187-induced TNF- $\alpha$ and IL- 6 secretion and reduced mRNA levels of TNF- $\alpha$, IL-6 and IL-8. HCT was observed to block the nuclear translocation of $\mathrm{NF}-\kappa \mathrm{B}$, inhibiting the phosphorylation of I $\mathrm{B} \alpha$ in stimulated HMC-1 cells. This indicates that HCT inhibits an allergic inflammatory response via inhibition of the NF- $\kappa \mathrm{B}$ signaling pathway in HMC-1 human mast cells.

\section{Materials and methods}

Preparation of HCT ethanol extract. HCT was purchased from Omniherb (Yeongcheon, Republic of Korea). A 100 g ground powder was extracted twice with $80 \% \mathrm{v} / \mathrm{v}$ ethanol using an ultra-sonicator (Branson, Danbury, CT, USA) for $30 \mathrm{~min}$ at room temperature. The resulting extract was filtered through a $0.22 \mu \mathrm{m}$ filter and concentrated to $\sim 100 \mathrm{ml}$ under reducing pressure. The ethanol extract was evaporated at $40^{\circ} \mathrm{C}$ (Eyela, Tokyo, Japan) and freeze-dried for $72 \mathrm{~h}$ (Matsushita, Kadoma, Japan). The powder from the extract was dissolved in DMSO and stored in aliquots at $-80^{\circ} \mathrm{C}$ until further analysis.

Reagents. Iscove's modified Dulbecco's medium (IMDM), fetal bovine serum (FBS), antibiotic-antimycotic and phosphate-buffered saline (PBS) were purchased from Gibco-BRL (Carlsbad, CA, USA). Phorbol 12-myristate 13-acetate (PMA) and A23187 were obtained from Sigma-Aldrich (St. Louis, MO, USA). The MTS assay kit was purchased from Promega Corporation (Madison, WI, USA) and the EZ-western detection kit was obtained from Daeil Lab (Daeil Lab Service Co., Seoul, Korea).

Antibodies. Anti-human TNF- $\alpha$ antibody, biotinylated anti-human TNF- $\alpha$ antibody and human TNF- $\alpha$ recombinant protein were obtained from R\&D Systems (Minneapolis, MN, USA). Anti-human IL-6/IL-8 antibody, biotinylated anti-human IL-6/IL-8 antibody and human IL-6/IL-8 recombinant protein were purchased from BD Biosciences (San Jose, CA, USA). Antibodies against NF- $\kappa$ B, p-I $\kappa \mathrm{B} \alpha$ and lamin B were purchased from Santa Cruz Biotechnology, Inc. (Santa Cruz , CA, USA). $\alpha$-tubulin antibody was from Sigma-Aldrich.

Cell culture. Human mast cells (HMC-1) were maintained as monolayer cultures in IMDM supplemented with 10\% FBS, $100 \mathrm{U} / \mathrm{ml}$ of penicillin and $100 \mu \mathrm{g} / \mathrm{ml}$ of streptomycin at $37^{\circ} \mathrm{C}$ in a humidified incubator under $5 \% \mathrm{CO}_{2}$ gas.

MTS assay. HMC-1 cells were seeded at a density of $1 \times 10^{6}$ cells/well in $24-w e l l$ plates, pretreated with various concentrations of HCT $(0.05-0.4 \mathrm{mg} / \mathrm{ml})$ for $1 \mathrm{~h}$ and incubated for $24 \mathrm{~h}$ in the absence or presence of PMA $(25 \mathrm{nM})$ plus A23187 $(1 \mu \mathrm{M})$. Following 24-h incubation, MTS reagents were added to the culture medium prior to the detection of absorbance at $490 \mathrm{~nm}$. Since the absorbance correlates to the viability of cells, the number of cells (\% of control) was calculated using the formula: cell number $(\%$ of control $)=$ (absorbance of cells treated with CJ or silibinin - absorbance of blank well)/(absorbance of control cells - absorbance of blank well) x 100 .

Measurement of pro-inflammatory cytokines by ELISA (enzyme-linked immunosorbent assay). HMC-1 cells $\left(1 \times 10^{6}\right)$ were incubated with various concentrations of HCT (0.05-0.2 mM) for $1 \mathrm{~h}$ and treated with PMA plus A23187 for $4 \mathrm{~h}$. To measure pro-inflammatory cytokines, 96-well plates were coated with anti-human TNF- $\alpha$, IL- 6 and IL- 8 monoclonal antibodies in $0.1 \mathrm{M}$ sodium carbonate buffer $(\mathrm{pH} 9.5)$ and then incubated overnight at $4{ }^{\circ} \mathrm{C}$. Following washing, the cells were blocked with $10 \%$ FBS in PBS and incubated at room temperature for $1 \mathrm{~h}$. Following additional washing, samples (culture supernatants) were incubated for $2 \mathrm{~h}$ at $37^{\circ} \mathrm{C}$ and washed with PBS containing $0.05 \%$ Tween-20 (PBST) and incubated with $0.2 \mu \mathrm{g} / \mathrm{ml}$ biotinylated anti-human TNF- $\alpha$, IL-6 and IL-8 antibodies at room temperature for $1 \mathrm{~h}$. Incubation with streptavidin-horseradish peroxidase and subsequent treatment with tetramethylbenzidine and hydrogen peroxide substrate in the dark was performed for 30 min together with washing and the reaction was terminated using $2 \mathrm{NH}_{2} \mathrm{SO}_{4}$. Color development was measured using a microplate reader at $450 \mathrm{~nm}$. The inhibition percentage of cytokine production was calculated using the equation: \% inhibition $=(\mathrm{A}-\mathrm{B}) \times 100 / \mathrm{A}$, where $\mathrm{A}$ and $\mathrm{B}$ are the cytokine production without and with $\mathrm{HCT}$, respectively.

RNA extraction and reverse transcription-polymerase chain reaction $(R T-P C R)$. Total cellular RNA was isolated using an easy-BLUE ${ }^{\mathrm{TM}}$ RNA extraction kit (Intron Biotechnology, Seoul, Korea) according to the manufacturer's instructions. Total RNA $(2 \mu \mathrm{g})$ was synthesized to cDNA using M-MLV reverse transcriptase (Invitrogen Life Technologies, Carlsbad, CA, USA) according to the manufacturer's instructions. PCR was conducted in a $20 \mu \mathrm{l}$ reaction mixture consisting of cDNA template, 10 pmol each gene-specific primer, 10X Taq buffer, $2.5 \mathrm{mM}$ dNTP mixture and 1 unit Taq DNA polymerase (Takara Korea Biomedical Inc, Seoul, Korea).PCR was performed using the primers: TNF- $\alpha, 5$ '-TGAGCACTGAAAGCATGATCC-3' and 5'-ATCACTCCAAAGTGCAGCAG-3'; IL-6, 5'-AACC TTTCCAAAGATGGCTGAA-3' and 5'-CAGGAACTGG ATCAGGACTTT-3'; IL-8, 5'-TCAGTGCATAAAGAC ATACTCC-3' and 5'-TGGCATCTTCACTGATTCTTG-3'; and GAPDH 5'-CGTCTTCACCACCATGGAGA-3' and 5'-CGGCCATCACGCCACAGTTT-3'. The sequencing involved thermal cycling at $95^{\circ} \mathrm{C}$ for $1 \mathrm{~min}$ (denaturation), $50^{\circ} \mathrm{C}$ for $1 \mathrm{~min}$ (annealing) and $72^{\circ} \mathrm{C}$ for $1 \mathrm{~min}$ (extension). The products were checked by agarose electrophoresis and analyzed using the ChemiDoc imaging system (Bio-Rad, Hercules, CA, USA).

Preparation of cytosolic and nuclear protein. Cells were incubated in buffer A [10 mM HEPES (pH 7.9), $10 \mathrm{mM} \mathrm{KCl,}$ $1.5 \mathrm{mM} \mathrm{MgCl} \mathrm{M}_{2}, 0.5 \mathrm{mM}$ dithiothreitol (DTT) and $0.2 \mathrm{mM}$ phenylmethylsulfonyl fluoride (PMSF)]. The cells were incubated on ice for $5 \mathrm{~min}$ and centrifuged at 4,000 $\mathrm{x} \mathrm{g}$ for $5 \mathrm{~min}$. The pellet was then lysed with buffer B [10 mM HEPES (pH 7.9), $10 \mathrm{mM} \mathrm{KCl}, 1.5 \mathrm{mM} \mathrm{MgCl}_{2}, 0.1 \% \mathrm{NP}-40,0.5 \mathrm{mM}$ 
DTT and 0.2 mM PMSF] and centrifuged at 5,000 rpm for $5 \mathrm{~min}$ at $4^{\circ} \mathrm{C}$. The cytoplasmic proteins were extracted from the supernatant and the pellet was resuspended in buffer $\mathrm{C}$ [20 mM HEPES (pH 7.9), $420 \mathrm{mM} \mathrm{NaCl}, 1.5 \mathrm{mM} \mathrm{MgCl}$, 25\% glycerol, $0.2 \mathrm{mM}$ EDTA, $0.5 \mathrm{mM}$ DTT and $0.2 \mathrm{mM}$ PMSF], incubated on ice for $30 \mathrm{~min}$ and then centrifuged at $5,000 \mathrm{rpm}$ for $10 \mathrm{~min}$ at $4^{\circ} \mathrm{C}$. Nuclear proteins were obtained from the supernatant.

Western blot analysis. An equal amount of protein in total cell extracts was separated by SDS-PAGE. Following electrophoresis, the proteins were transferred to a nitrocellulose membrane (Schleicher \& Schuell Bioscience, Dassel, Germany). The membrane was blocked, incubated overnight

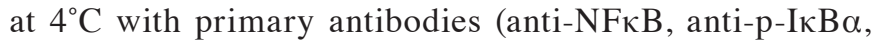
anti-lamin B and anti- $\alpha$-tubulin), washed with PBST $(0.1 \%$ PBS) and incubated with appropriate HRP-conjugated secondary antibodies at room temperature for $1 \mathrm{~h}$. Immunoreactive protein was developed using an EZ-western detection kit (Daeillab Service Co., Seoul, South Korea).

Statistical analysis. Data are presented as the mean \pm SD. A Student's t-test was used for single variable comparisons. $\mathrm{P}<0.05$ was considered to indicate a statistically significant difference.

\section{Results}

Effect of HCT on cell viability in activated mast cells. Mast cells are activated by PMA and A23187 and secrete inflammatory mediators, including histamine, serotonin, hydrolase, heparin and prostaglandin. In the current study, the effect of HCT on cell viability in HMC-1 cells was investigated. It was observed that HCT did not affect cell viability in HMC-1 cells (Fig. 1). HCT failed to decrease histamine release induced by PMA plus A23187 (data not shown).

Effect of HCT on PMA plus A23187-stimulated TNF- $\alpha$ expression. Pro-inflammatory cytokines are important factors of allergic inflammation. Therefore, the production and expression of TNF- $\alpha$ was determined by ELISA or RT-PCR to evaluate the effect of HCT on the pro-inflammatory cytokines. It was observed that HCT significantly decreased TNF- $\alpha$ production induced by PMA plus A23187 (Fig. 2A). In addition, mRNA levels of TNF- $\alpha$ induced by PMA plus A23187 was reduced by HCT treatment (Fig. 2B).

Effect of HCT on PMA plus A23187-stimulated IL-6 expression. The production and expression of IL- 6 by ELISA or RT-PCR was determined. HCT significantly decreased IL-6 production induced by PMA plus A23187 (Fig. 3A). In addition, IL-6 mRNA levels induced by PMA plus A23187 were also reduced by HCT treatment (Fig. 3B).

Effect of HCT on PMA plus A23187-stimulated IL-8 expression. The production and expression of IL- 8 was measured by ELISA and RT-PCR. HCT was not found to significantly decrease the production levels of IL- 8 induced by PMA plus A23187 (Fig. 4A). However, mRNA levels of IL-8 induced by PMA plus A23187 were reduced by HCT (Fig. 4B).

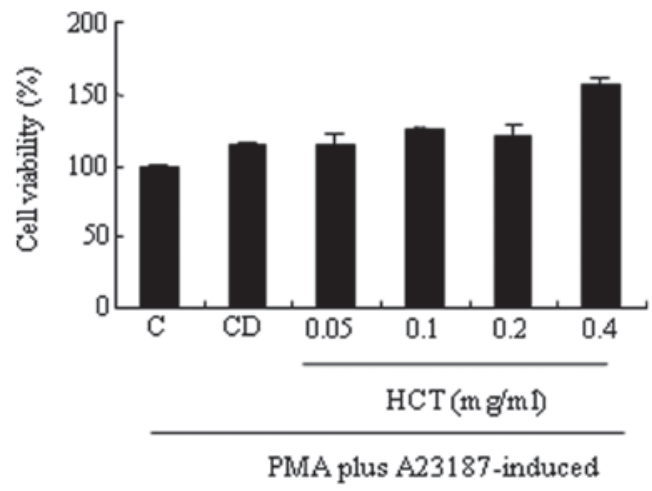

Figure 1. Effect of HCT on cell viability in activated mast cells. HMC-1 cells $\left(1 \times 10^{6}\right.$ cells $\left./ \mathrm{ml}\right)$ were pretreated with the indicated concentrations of HCT (0.05 - $0.4 \mathrm{mg} / \mathrm{ml})$ for $1 \mathrm{~h}$ and incubated with PMA and A23187 for $24 \mathrm{~h}$. Cell viability was determined by MTS assay. Data are presented as the mean $\pm \mathrm{SD}$ of three independent experiments. C, induced control; $\mathrm{CD}$, induced control with DMSO treatment; HCT, Houttuynia cordata Thunb.

A

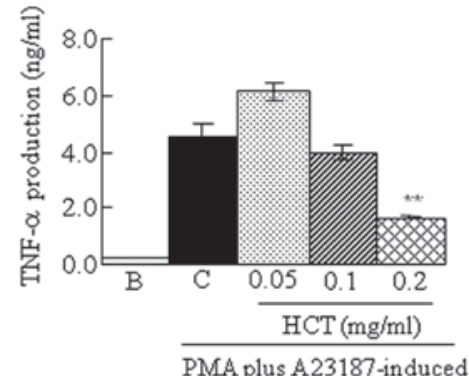

B
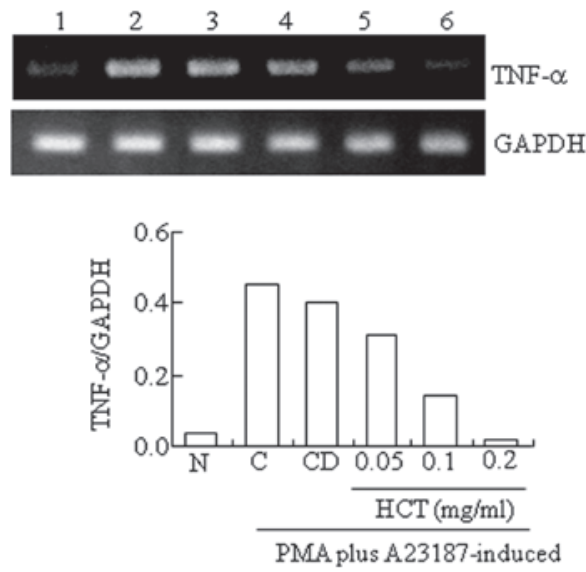

Figure 2. Effect of HCT on PMA plus A23187-stimulated TNF- $\alpha$ expression. HMC-1 cells $\left(1 \times 10^{6}\right.$ cells $\left./ \mathrm{ml}\right)$ were pre-incubated with various concentrations of HCT $(0.05-0.2 \mathrm{mg} / \mathrm{ml})$ for $1 \mathrm{~h}$ and treated with PMA plus A23187 for $4 \mathrm{~h}$. (A) TNF- $\alpha$ secreted protein levels in the supernatant were measured by ELISA assay. (B) TNF- $\alpha$ mRNA levels were measured by RT-PCR. Lanes 1, normal cells; 2, control cells; 3 , DMSO control cells; 4, HCT $(0.05 \mathrm{mg} / \mathrm{ml})+$ PMA plus A23187; 5, HCT $(0.1 \mathrm{mg} / \mathrm{ml})+$ PMA plus A23187; 6, HCT $(0.2 \mathrm{mg} / \mathrm{ml})+$ PMA plus A23187. Data are presented as the mean \pm SD of three independent experiments ( $\mathrm{P}<0.05$ and ${ }^{* *} \mathrm{P}<0.01$, vs. control). N, no treatment; $\mathrm{C}$, induced control; $\mathrm{CD}$, induced control with DMSO treatment; HCT, Houttuynia cordata Thunb; ELISA, enzyme-linked immunosorbent assay; RT-PCR, reverse transcription polymerase chain reaction.

Effect of HCT on PMA plus A23187-stimulated NF- $\kappa B$ activation and $I \kappa B \alpha$ phosphorylation. Expression of pro-inflammatory cytokines, including TNF- $\alpha$, IL-6 and IL-8, 
A

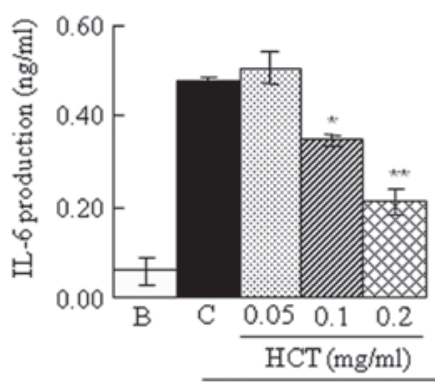

PMA plus A23187-induced

B
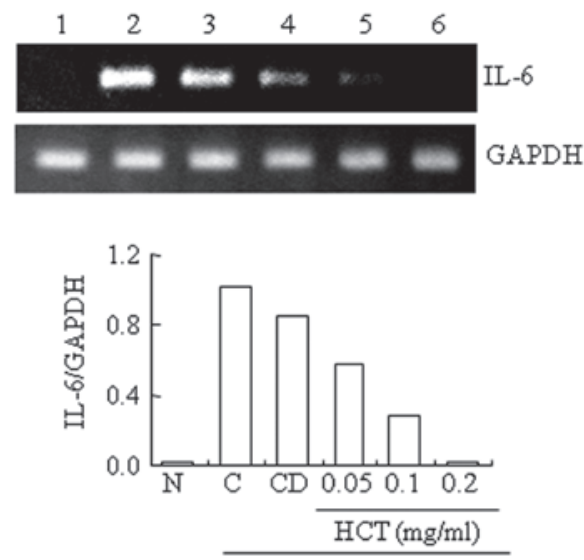

PMA plus A23187-induced
A

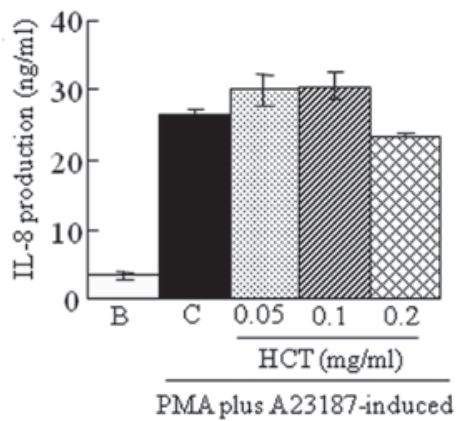

B
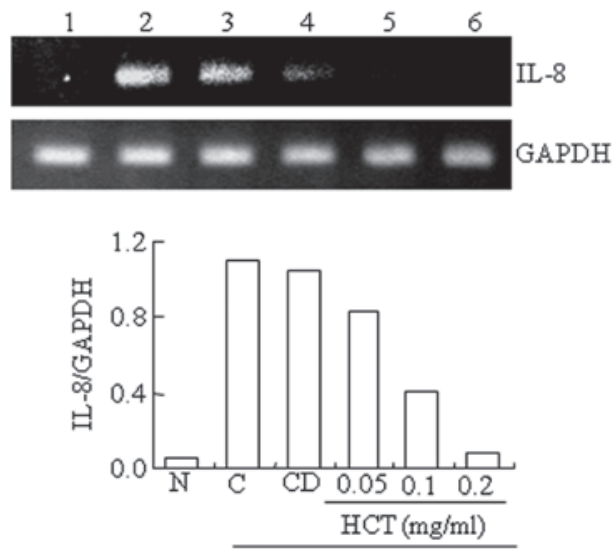

PMA plus A23187-induced
Figure 3. Effect of HCT on PMA plus A23187-stimulated IL-6 expression. HMC-1 cells $\left(1 \times 10^{6}\right.$ cells $\left./ \mathrm{ml}\right)$ were preincubated with various concentrations of HCT $(0.05-0.2 \mathrm{mg} / \mathrm{ml})$ for $1 \mathrm{~h}$ and treated with PMA plus A23187 for $4 \mathrm{~h}$ (A and B). (A) IL-6 secreted protein levels in the supernatant were measured by ELISA assay. (B) IL-6 mRNA levels were measured by RT-PCR Lanes 1, normal cells; 2, control cells; 3, DMSO control cells; 4, HCT $(0.05 \mathrm{mg} / \mathrm{ml})+$ PMA plus A23187; 5 . HCT $(0.1 \mathrm{mg} / \mathrm{ml})+$ PMA plus A23187; 6 , HCT $(0.2 \mathrm{mg} / \mathrm{ml})+$ PMA plus A23187. Data are presented as the mean \pm SD of three independent experiments ( ${ }^{*} \mathrm{P}<0.05$ and ${ }^{* *} \mathrm{P}<0.01$ vs. control). N, no treatment; $\mathrm{C}$, induced control; $\mathrm{CD}$, induced control with DMSO treatment; HCT, Houttuynia cordata Thunb; ELISA, enzyme-linked immunosorbent assay; RT-PCR, reverse transcription polymerase chain reaction.

is regulated by NF- $\mathrm{BB}$ signaling. The effect of HCT on the expression of NF- $\mathrm{KB}$ signaling molecules was analyzed and $\mathrm{HCT}$ was found to suppress the expression of nuclear NF- $\mathrm{kB}$ induced by PMA plus A23187 (Fig. 5). In addition, HCT inhibited the phosphorylation of IкB $\alpha$ in stimulated HMC-1 cells indicating that HCT abrogates the dissociation of from the NF- $\mathrm{KB}$ heterodimer (p65 and p50) to suppress NF- $\mathrm{KB}$ signaling (Fig. 5).

\section{Discussion}

Mast cells are major immune cells involved in allergies with versatile physiological functions and are important for allergic activities in response to the stimuli-induced release of histamine (21-23). In addition, the inhibition of TNF- $\alpha$, IL-6, IL-8 and NF- $\mathrm{KB}$ activation has been shown as an indicator of anti-inflammatory events in mast cells $(21,24)$. Although several traditional herbal medicines have been shown to have inhibitory effects on allergy or inflammation using mast cells $(25,26)$, there is little information with regard to the effects of HCT on mast cell-derived allergic inflammation or
Figure 4. Effect of HCT on PMA plus A23187-stimulated IL-8 expression. HMC-1 cells $\left(1 \times 10^{6}\right.$ cells $\left./ \mathrm{ml}\right)$ were preincubated with various concentrations of HCT $(0.05-0.2 \mathrm{mg} / \mathrm{ml})$ for $1 \mathrm{~h}$ and treated with PMA plus A23187 for $4 \mathrm{~h}$ (A and B). (A) IL-8 secreted protein levels in the supernatant were measured by ELISA assay. (B) IL-8 mRNA levels were measured by RT-PCR. Lanes 1, normal cells; 2, control cells; 3, DMSO control cells; 4, HCT $(0.05 \mathrm{mg} / \mathrm{ml})+$ PMA plus A23187; 5, HCT $(0.1 \mathrm{mg} / \mathrm{ml})+$ PMA plus A23187; 6, HCT $(0.2 \mathrm{mg} / \mathrm{ml})+$ PMA plus A23187. Data are presented as the mean \pm SD of three independent experiments. $\mathrm{N}$, no treatment; $\mathrm{C}$, induced control; CD, induced control with DMSO treatment; HCT, Houttuynia cordata Thunb ELISA, enzyme-linked immunosorbent assay; RT-PCR, reverse transcription polymerase chain reaction.

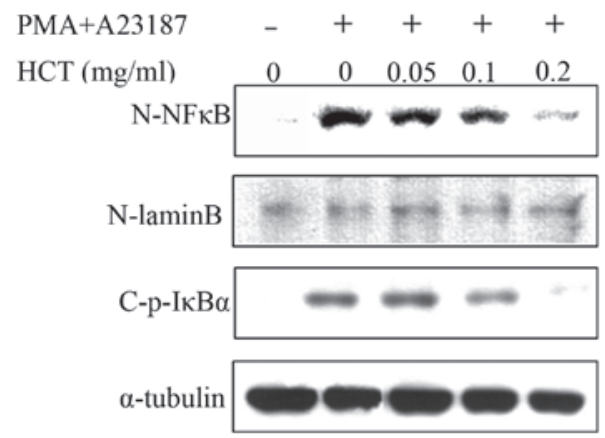

Figure 5. Effect of HCT on PMA plus A23187-stimulated NF-кB activation and IкB $\alpha$ phosphorylation. HMC- 1 cells $\left(1 \times 10^{6}\right.$ cells $\left./ \mathrm{ml}\right)$ were incubated with HCT $(0.05-0.2 \mathrm{mg} / \mathrm{ml})$ for $1 \mathrm{~h}$ and stimulated with PMA plus A23187 for $2 \mathrm{~h}$. Nuclear and cytoplasmic proteins were isolated by lysis buffer and examined for NF- $\kappa \mathrm{B}$ and $\mathrm{p}-\mathrm{I} \kappa \mathrm{B} \alpha$ by western blot analysis. N, nuclear extract; C, cytosol extract; HCT, Houttuynia cordata Thunb.

the molecular mechanisms involved. Therefore, in the present study, we investigated whether HCT has a therapeutic effect on allergic inflammatory disease. Since PMA alone fails to 
induce the degranulation of mast cells, HMC-1 cells were stimulated by PMA and A23187. Notably, HCT inhibited PMA plus A23187-induced TNF- $\alpha$ and IL-6 secretion and reduced mRNA levels of TNF- $\alpha$, IL-6 and IL-8. In agreement with the current observations, it was previously reported that HCT inhibits the secretion of TNF- $\alpha$ in the activated macrophage-like cell line, RAW 264.7 (27).

Allergic inflammation is classified into early-phase (or type I immediate hypersensitivity) and late-phase reactions, which result in subsequent chronic allergic inflammation. Release of histamine and other mediators following the crosslinking of the Fc receptor subsequent to the binding of $\operatorname{IgE}(\mathrm{FceRI})$ to allergen in mast cells is known as early-phase reaction. The IgE-mediated PCA reaction is a sensitive reaction for the detection of small quantities of antibodies and has been used to evaluate the mechanisms of immediate allergy reaction (28). These early-phase responses are followed by a late-phase reaction that typically develops 2-9 $\mathrm{h}$ following allergen exposure. In late-phase reactions, the recruitment of leucocytes, including T-cells and neutrophils, is featured $(21,29,30)$. The transition to the late-phase reaction is characterized as the recruitment of leukocytes by upregulating mediators, including IL-8 and TNF- $\alpha(21,30)$. Mast cell-derived IL- 8 is hypothesized to activate neurophils in allergic inflammation (31). In a previous study, it was reported that monomeric IgE induces long-lasting IL-8 synthesis in mast cells (32). It was also reported that TNF- $\alpha$ is crucial in the development of late-phase anaphylactic reactions via the PAF-mediated $\mathrm{NF}-\kappa \mathrm{B}$-dependent pathway and initiates late-phase allergic inflammation (33). Therefore, the observation of no significant change in histamine release, but significant suppression of inflammatory cytokines, indicates that HCT may have inhibitory effects on allergic inflammation through transition or late-phase reaction.

$\mathrm{NF}-\kappa \mathrm{B}$ plays a key role in the cellular stress response and in inflammation by controlling the expression of a network of genes, including TNF- $\alpha$, IL- 6 and IL- 8 . Following infection, microbial pathogens are sensed by the host and activate $\mathrm{NF}-\kappa \mathrm{B}$ transcription factors via triggering of various sensors, including the toll-like receptors, which are expressed on cells of the innate immune system, macrophages, dendritic cells and mucosal epithelial cells $(34,35)$. NF- $\kappa \mathrm{B}$ activation is closely controlled by a pathway that regulates the proteolysis of the inhibitory I $\mathrm{K}$ B and I $\mathrm{KB}$-associated proteins. In unstimulated cells, $\mathrm{NF}-\kappa \mathrm{B}$ dimers are sequestered in the cytoplasm via physical association with $\mathrm{NF}-\kappa \mathrm{B}$ inhibitory proteins, I $\kappa \mathrm{Bs}(34)$. Upon stimulation, signal transduction events rapidly lead to the activation of the IкB kinase (IKK) complex, composed of two catalytic subunits (IKK $\alpha$ and IKK $\beta$ ) and a regulatory subunit, NF- $\mathrm{B}$ essential modulator (34). Activated IKK phosphorylates I $\mathrm{B} \alpha$, predominantly via the action of IKK $\beta$, triggering its polyubiquitination and proteasomal degradation and inducing the nuclear translocation of associated $N F-\kappa B$ subunits (34). $\mathrm{NF}-\kappa \mathrm{B}$ subunits bind to specific DNA to induce the transcription of target genes. The current observations indicate that HCT suppresses the nuclear translocation of NF- $\kappa \mathrm{B}$ as well as the phosphorylation of $\mathrm{I} \kappa \mathrm{B} \alpha$, which may inhibit the expression of proinflammatory cytokines, including TNF- $\alpha$, IL-6 and IL-8.

Results of the present study suggest that HCT inhibits the production of pro-inflammatory cytokines via inhibition of the
$\mathrm{NF}-\kappa \mathrm{B}$ signaling pathway in HMC-1 human mast cells. We hypothesized that HCT may be a potential therapeutic target for the treatment of allergies and inflammatory diseases.

\section{Acknowledgements}

This study was supported by a grant of the Traditional Korean Medicine R\&D Project, Ministry of Health \& Welfare, Republic of Korea (no. B110043). This research was also supported by Basic Science Research Program through the National Research Foundation of Korea (NRF) funded by the Ministry of Education, Science and Technology (no. 2012R1A1A3004797).

\section{References}

1. Ferrero-Miliani L, Nielsen OH, Andersen PS and Girardin SE: Chronic inflammation: importance of NOD2 and NALP3 in interleukin-lbeta generation. Clin Exp Immunol 147: 227-235, 2007.

2. Rosenwasser LJ: Current understanding of the pathophysiology of allergic rhinitis. Immunol Allergy Clin North Am 31: 433-439, 2011.

3. Rose S, Weld-Moore R, Ghazali N and Newman L: 'I've got hay-fever and my mouth is stinging!'. Br Dent J 211: 369-370, 2011.

4. Olivera A and Rivera J: An emerging role for the lipid mediator sphingosine-1-phosphate in mast cell effector function and allergic disease. Adv Exp Med Biol 716: 123-142, 2011.

5. Kuna P, Reddigari SR, Rucinski D, Oppenheim JJ and Kaplan AP: Monocyte chemotactic and activating factor is a potent histamine-releasing factor for human basophils. J Exp Med 175: 489-493, 1992.

6. Wang SL, Malany S, Wang Q, Santos MA, Crowe PD and Maki RA: Histamine induces interleukin- 6 expression in the human synovial sarcoma cell line (SW982) through the H1 receptor. Inflamm Res 55: 393-398, 2006.

7. Thomas PS: Tumor necrosis factor-alpha: the role of this multifunctional cytokine in asthma. Immunol Cell Biol 79: 132-140, 2001.

8. Nakae S, Suto H, Kakurai M, Sedgwick JD, Tsai M and Galli SJ: Mast cells enhance $\mathrm{T}$ cell activation: Importance of mast cell-derived TNF. Proc Natl Acad Sci USA 102: 6467-6472, 2005.

9. Bodreau RT, Hoskin DW and Lin TJ: Phosphatase inhibition potentiates IL- 6 production by mast cells in response to FcepsilonRI-mediated activation: involvement of p38 MAPK. J Leukoc Biol 76: 1075-1081, 2004.

10. Murayama T, Mukaida N, Sadanari H, Yamaguchi N, Khabar KS, Tanaka J, Matsushima K, Mori S and Eizuru Y: The immediate early gene 1 product of human cytomegalovirus is sufficient for up-regulation of interleukin-8 gene expression. Biochem Biophys Res Commun 279: 298-304, 2000.

11. Kuprsh DV, Udalova IA, Turetskaya RL, Rice NR and Nedospasov SA: Conserved kappa B element located downstream of the tumor necrosis factor alpha gene: distinct NF-kappa B binding pattern and enhancer activity in LPS activated murine macrophages. Oncogene 11: 97-106, 1995.

12. Galien R, Evans HF and Garcia T: Involvement of CCAAT/ enhancer-binding protein and nuclear factor-kappa B binding site in interleukin-6 promoter inhibition by estrogens. Mol Endocrinol 10: 713-722, 1996.

13. Chang JS, Chiang LC, Chen CC, Liu LT, Wang KC and Lin CC: Antileukemic activity of Bidens pilosa L. var. minor (Blume) Sherff and Houttuynia cordata Thunb. Am J Chin Med 29: 303-312, 2001.

14. Chiang LC, Chang JS, Chen CC, Ng LT and Lin CC: Anti-herpes simplex virus activity of Bidens pilosa and Houttuynia cordata. Am J Chin Med 31: 355-362, 2003.

15. Li GZ, Chai OH, Lee MS, Han EH, Kim HT and Song CH: Inhibitory effects of Houttuynia cordata water extracts on anaphylactic reaction and mast cell activation. Biol Pharm Bull 28: 1864-1868, 2005.

16. Lu HM, Liang YZ, Yi LZ and Wu XJ: Anti-inflammatory effect of Houttuynia cordata injection. J Ethnopharmacol 104: 245-249, 2006. 
17. Chen YY,Liu JF, Chen CM, Chao PY and Chang TJ: A study of the antioxidative and antimutagenic effects of Houttuynia cordata Thunb. using an oxidized frying oil-fed model. J Nutr Sci Vitaminol (Tokyo) 49: 327-333, 2003.

18. Kim IS, Kim JH, Kim JS, Yun CY, Kim DH and Lee JS: The inhibitory effect of Houttuynia cordata extract on stem cell factor-induced HMC-1 cell migration. J Ethnopharmacol 112: 90-95, 2007.

19. Lee JS, Kim IS, Kim JH, Kim JS, Kim DH and Yun CY: Suppressive effects of Houttuynia cordata Thunb (Saururaceae) extract on Th2 immune response. J Ethnopharmacol 117: 34-40, 2008.

20. Tang YJ, Yang JS, Lin CF, Shyu WC, Tsuzuki M, Lu CC, Chen YF and Lai KC: Houttuynia cordata Thunb extract induces apoptosis through mitochondrial-dependent pathway in HT-29 human colon adenocarcinoma cells. Oncol Rep 22: 1051-1056, 2009.

21. Bischoff SC: Role of mast cells in allergic and non-allergic immune responses: comparison of human and murine data. Nat Rev Immunol 7: 93-104, 2007.

22. Mekori YA and Metcalfe DD: Mast cells in innate immunity. Immunol Rev 173: 131-140, 2000.

23. Prussin C and Metcalfe DD: 4. IgE, mast cells, basophils and eosinophils. J Allergy Clin Immunol 111 (2 Suppl): S486-S494, 2003.

24. Kim SJ, Lee EJ, Song YS, Jeong HJ, Lee KM, Kim HR, Chae HJ, Shin TY, Kim YK, Hong SH and Kim HM: Cheongyeolsaseuptang inhibits production of TNF-alpha, IL-6 and IL-8 as well as NF-kappa B activation in human mast cells. J Ethnopharmacol 97: 83-88, 2005.

25. Cha JY, Jung JY, Jung JY, Lee JR, Cho IJ, Ku SK, Byun SH, Ahn YT, Lee CW, Kim SC and An WG: Inhibitory effects of traditional herbal formula pyungwi-san on inflammatory response in vitro and in vivo. Evid Based Complement Alternat Med 2013: 630198, 2013.
26. Kim SR, Choi HS, Seo HS, Choi YK, Shin YC and Ko SG: Topical application of herbal mixture extract inhibits ovalbumin- or 2,4-dinitrochlorobenzene-induced atopic dermatitis. Evid Based Complement Alternat Med 2012: 545497, 2012.

27. Park E, Kum S, Wang C, Park SY, Kim BS and Schuller-Levis G: Anti-inflammatory activity of herbal medicines: inhibition of nitric oxide production and tumor necrosis factor-alpha secretion in an activated macrophage-like cell line. Am J Chin Med 33: 415-424, 2005.

28. Harada M, Nagata M and Takeuchi M: Production of passive cutaneous anaphylaxis (PCA) and reversed PCA by rat IgE antibody in the mouse. Experientia 44: 459-462, 1988

29. Valenta R: The future of antigen-specific immunotherapy of allergy. Nat Rev Immunol 2: 446-453, 2002.

30. Galli SJ, Tsai M and Piliponsky AM: The development of allergic inflammation. Nature 454: 445-454, 2008.

31. Lippert U, Möller A, Welker P, Artuc M and Henz BM: Inhibition of cytokine secretion from human leukemic mast cells and basophils by H1- and H2-receptor antagonists. Exp Dermatol 9: 118-124, 2000.

32. Cruse G, Kaur D, Yang W, Duffy SM, Brightling CE and Bradding P: Activation of human lung mast cells by monomeric immunoglobulin E. Eur Respir J 25: 858-863, 2005.

33. Choi IW, Kim YS, Kim DK, Choi JH, Seo KH, Im SY, Kwon KS Lee MS, Ha TY and Lee HK: Platelet-activating factor-mediated NF-kappaB dependency of a late anaphylactic reaction. J Exp Med 198: 145-151, 2003.

34. Mohamed MR and McFadden G: NFkB inhibitors: strategies from poxviruses. Cell Cycle 8: 3125-3132, 2009.

35. Medzhitov R: Toll-like receptors and innate immunity. Nat Rev Immunol 1: 135-145, 2001. 